\title{
Experience with utilization of auto-expandable stents introduced through the femoral artery for treatment of thoracic aortic diseases
}

\author{
Experiência com o uso de endoprótese auto-expansível (stent) introduzida através da artéria femoral \\ para tratamento das doenças da aorta torácica descendente
}

João Roberto BREDA ${ }^{1}$, Dirceu Rodrigues ALMEIDA, Roberto Álvaro RAMOS FILHO, Marcelo Grandini SILAS, Adilson Casemiro PIRES

RBCCV 44205-626

\section{Abstract}

Introduction: The authors describe their experience with the implantation of endovascular self-expanding stent-grafts for the treatment of descending aortic thoracic diseases.

Method: From June 1996 to April 2002, 14 endovascular self-expanding stent-grafts were implanted, 10 in acute type $B$ dissections, 3 in atherosclerotic aneurysms and 1 in a penetrating aortic ulcer. The patient's ages varied between 43 and 77 years (mean $=63.3$ years). In the majority of cases the procedure was performed under general anesthesia. The delivery of the stent-graft endoprostheses was performed using the trans-femoral system.

Results: There was one death on the sixth postoperative day by pulmonary thromboembolism. One patient was operated on for the implantation of an endovascular selfexpanding stent-graft through the aortic arch under deep hypothermia and circulatory arrest, and died eight months after operation. All the survivors were well and imaging studies showed adequate correction of the aortic disease.

Conclusion: Preliminary results suggest that this technique will contribute to improve surgical results in the treatment of descending thoracic aortic diseases.

Descriptors: Aneurysm dissecting, surgery. Aortic aneurysm, surgery. Femoral artery, surgery.

\section{Resumo}

Introdução: Os autores descrevem a experiência com a utilização de endoprótese auto-expansível para tratamento das doenças da aorta torácica descendente.

Método: No período de junho de 1996 a abril de 2002, 14 pacientes foram submetidos à correção de doenças da aorta torácica descendente, utilizando-se a técnica endoluminal com implante do stent aórtico. Do total de 14 pacientes, 10 eram portadores de disseccão aguda do tipo $B, 3$ de aneurisma aterosclerótico e 1 de úlcera penetrante de aorta. As idades variaram de 43 a 77 anos, com média de 63,3 anos.

Resultados: Houve um óbito, no sexto dia de pósoperatório, por tromboembolismo pulmonar. Um paciente foi encaminhado para tratamento cirúrgico eletivo, tendo sobrevivido por 8 meses. Os sobreviventes estão bem clinicamente e com estudo por imagem mostrando correção da doença.

Conclusão: Resultados preliminares sugerem que esta técnica representa uma alternativa para tratamento das doenças da aorta torácica descendente.

Descritores: Aneurisma dissecante, cirurgia. Aneurisma aórtico, cirurgia. Artéria femoral, cirurgia.

\footnotetext{
Work performed in the teaching Hospital of the Medical School, Foundation of ABC

1 - Cardiovascular Surgery Department of the Medical School, Foundation of $\mathrm{ABC}$

Correspondence address: João Roberto Breda. Rua Antonio Bastos, 755 - Apto. 31. Santo André, SP. CEP: 09040-220. Tel: (11) 44384311. E mail: jrbreda@hotmail.com
} 


\section{INTRODUCTION}

The use of stent-grafts in the treatment of descending thoracic aorta diseases has become a reality in the last few years, over all due to the advent of the femoral artery approach in the hemodynamic laboratory [1-5].

The utilization of this alternative therapy is justified by the reduction in the surgical morbidity and mortality rates when compared with the traditional techniques $[4,6]$. Thus, the endoluminal treatment has become an acceptable alternative in the treatment of dissections and true aneurysms of the descending thoracic aorta.

The aim of this work is to report on the experience with the use of stent-grafts introduced through the femoral artery for the treatment of descending aorta disease in the $\mathrm{ABC}$ Medical school.

\section{METHOD}

In the period from June 1996 to April 2002, 14 patients were submitted to correction of descending aorta diseases utilizing the endoluminal technique with the implant of an aortic stent-graft. Of the total of 14 patients, 10 suffered from type B acute aortic dissections, 3 from atherosclerotic aneurysms and 1 from a penetrating ulcer of the aorta.

The risk factors associated to the diseases can be seen in Table 1.

Table 1. Risk factors associated to the disease

\begin{tabular}{lc}
\hline ASSOCIATED RISK FACTORS & $\%$ \\
\hline Systemic arterial hypertension & 100 \\
Chronic obstructive pulmonary disease & 21.4 \\
Marfan's syndrome & 14.2 \\
Chronic renal failure & 7.1 \\
Chronic heart failure & 7.1 \\
\hline
\end{tabular}

The ages ranged from 43 to 77 years with a mean of 63.3 years. Nine of the patients were male and 5 female.

Diagnostic confirmation was with the help of the following methods: angiography, axial or helical computed tomography, magnetic nuclear resonance and transesophageal echocardiography performed either in isolation or associated.

In relation to the pre-operative complications, persistent thoracic pain was the most frequently found $(71.4 \%$ of the patients), followed by expansion of the false lumen in the dissections $(35.7 \%$ of the patients) or expansion of the rupture of the aorta in the true aneurysms $(28.5 \%$ of the patients). In three cases acute renal failure was observed (21.4\%) and in 1 case hemodialysis was necessary (Table 2).

Table 2. Pre-operative complications

\begin{tabular}{ll}
\hline Complications & $\%$ \\
\hline Persistent thoracic pain & 71.4 \\
Expansion of the false lumen & 35.7 \\
Expansion of the aortic rupture & 28.5 \\
Acute renal failure & 21.4 \\
Mesenteric ischemia & 7.1 \\
\hline
\end{tabular}

The aortic stent-graft utilized in our institution is the one currently manufactured by Braile Biomedica in São José do Rio Preto, Brazil and which was developed in the Paulista School of Medicine, Federal University of São Paulo.

The patients were treated in the hemodynamic laboratory, 10 of whom were operated on under general anaesthetic. Monitoring involved continuous oximetry, mean arterial pressure and surface electrocardiography. Control of the insertion of the stent-graft in the aortic lumen was by means of angiography.

Surgical isolation of the femoral artery, the chosen site for the insertion of the stent-graft, was performed and then after the administration of 5,000 units of heparin via endovenous, a femoral arteriotomy was performed between two vascular clamps.

Thus, the catheter containing the stent-graft was delicately introduced to the iliac-femoral system and its progression was controlled by radioscopy. Once the determined site in the aorta of the stent-graft was reached, the stent-graft was released by the backward movement of the sheath of the catheter with the mean arterial pressure controlled (maintained between 50 and $60 \mathrm{mmHg}$ ).

The choice of the diameter and length is based on an analysis of pre-operative examinations, where a stent 10 to $20 \%$ bigger than the diameter of the aorta is always used.

After the liberation of the stent, another aortography was performed to assess the result by observing the occlusion of the lesion of the intima in the case of dissections or exclusion of the aneurysmal sac in the true aneurysms.

The follow up periods after stent-graft implantation varied from 1 to 62 post-operative months, with a mean of 21.5 months. All the patients underwent control tomographies after the endovascular procedure.

\section{RESULTS}

The result of the procedure was considered to be successful when the stent-graft was seen in the correct 

aortic diseases

position and occlusion of the intimal lesion occurred in the cases of dissection and exclusion of the aneurysmal sac in the true aneurysms. This happened in 13 cases $(92.6 \%)$ where the stent-graft was successfully liberated and in 2 of these cases intentional occlusion of the left subclavian artery was achieved without clinical repercussions.

In 1 case liberation of the stent-graft was unsuccessful due to excessive curving of the distal portion of the aortic arch and the patient underwent an elective operation with surgical placement of the stent-graft by median sternotomy. This patient survived for 8 months when re-dissection occurred with expansion of the false lumen and the patient underwent reoperation with death during the postoperative period.

The periods in the intensive care unit ranged from 6 hours to 6 days with an average of 24.8 hours with hospitalization after the procedure varying from 3 to 6 days (mean 3.76 days).

The post-operative complications were: prolonged pain after the implant (35.7\%), prolonged fever after the implant $(21.4 \%)$, proximal leakage $(14.2 \%)$, petechia of the lower limbs $(7.1 \%)$, transient amaurosis $(7.1 \%)$, splenic infarction $(7.1 \%)$ and femoral bleeding with the necessity of blood transfusion $(7.2 \%)$ - Table 3 .

Table 3. Post-operative complications

\begin{tabular}{ll}
\hline Post-operative complications & $\%$ \\
\hline Prolonged pain (> 3 days) & 35.7 \\
Prolonged fever (> 3 days) & 21.4 \\
Proximal leakage & 14.2 \\
Petechia of the lower limbs & 7.1 \\
Transient amaurosis & 7.1 \\
splenic infarction & 7.1 \\
Femoral bleeding & 7.1 \\
\hline
\end{tabular}

One death occurred on the sixth post-operative day due to pulmonary thromboembolism.

The 13 patients who were released from hospital underwent control tomographies after the procedure, in two of whom a slight leak in the proximal portion of the stentgraft was evidenced which became occluded before the sixth post-operative month.

\section{COMMENTS}

Diseases of the aorta located on the aortic arch and in the descending portion present with a greater risk and more frequent complications than diseases of the ascending aorta.
Aiming to improve the results of treatment of aneurysms and dissections of the descending thoracic aorta, new techniques have been developed, among which the use of stent-grafts are notable [5,7]

Traditionally, the only effective treatment for patients with aneurysms of the descending thoracic aorta was the substitution of the aneurysmal portion of the aorta with a graft by left thoracotomy, a procedure associated with substantial morbidity and mortality of the patients [7].

The treatment of aortic aneurysms with stent-grafts initiated with the concept introduced by DOTTER [1] in 1969. In 1991, PARODI et al. [2] widely publicized the percutaneous treatment, reporting the success obtained with the use of prostheses expanded by balloon in the treatment of aneurysms of the abdominal aorta. In 1994, DAKE et al. [3] published their experience in the treatment of aneurysms of the descending thoracic aorta using stent-grafts.

Based on the concept of the 'elephant trunk' technique [8], BUFFOLO AND PALMA [9], PALMA et al. [4] and following this, STOLF et al. [5] started to use stents in the treatment of acute and chronic descending aortic dissections, by median sternotomy with satisfactory results. Thus, with the acquired experience in the surgical center associated with the use of endoscopic vision of the aorta and after experimental trials in dogs, it was possible to expand the use of endoprostheses by the femoral artery approach in the hemodynamics laboratory $[4,6,10,11]$.

Aneurysms and dissections of the descending thoracic aorta are still a challenge in medicine, and so several centers around the world have studied and published their results of this therapeutic option represented by the use of stentgrafts introduced by the femoral artery [8, 13-20].

In the period from July 1992 to October 1997, a total of 103 patients were submitted to endovascular treatment in Stanford University. In comparison, in the same institution over the same period, 186 patients with aneurysms or dissections of the descending aorta were treated by conventional open surgery. In this series, the main complication was leakage of the proximal portion of the stentgraft in $24 \%$ of the cases, which probably is associated to anatomical characteristics of the curvature of the distal portion of the aortic arch and the start of the left subclavian artery. The other complications were severe respiratory failure $912 \%$ ), stroke $(7 \%)$, acute renal failure $(5 \%)$ and paraplegia/paraparesis (3\%). The hospital mortality rate was $9 \%$ and the related factors were cerebral hemorrhage, sepsis and multiple organ and systemic failure [7].

Leakage in the proximal portion of the stent was observed as the main complication of the method by other authors [18]. The solution to this problem involves the use of another prosthesis in an attempt to occlude the intimal gap, as well as embolization with a 'spring' at the site of the leakage $[7,18]$. Incomplete closure of the intimal gap with consequent 

aortic disease

maintenance of the blood flow to the interior of the aneurysm or in the aortic false lumen (in the case of dissections) has been reported as a bad prognostic factor after endoluminal repairs [12].

In the hospital of the ABC Medical School, we started our experience in 1996 and the complications related to this work have already been published in other papers. It is important to note that the fever in the post-operative period can be explained by the intense inflammatory reaction between the tissue that lines the stent-graft and the aortic wall. In these cases a good clinical evolution of the patients has been observed until now [6].

Despite of the theoretical advantages with the use of stent-grafts in the aorta and the technological efforts for its development, the method involves some limitations. These include the necessity of adequate vascular access, the impossibility of re-implantation of the aortic vessels, the necessity of proximal and distal necks to anchor in the wall of the aorta and even the possibility of migration of the endoprosthesis.

Thus, preliminary results such as in our study suggest that this technique represents a safe alternative when compared to conventional surgery, although investigations of the late follow-up are necessary to confirm the use of the technique as the method of choice.

\section{BIBLIOGRAPHIC REFERENCES}

1. Dotter CT. Transluminally-placed coilspring endarterial tube grafts: long-term patency in canine popliteal artery. Invest Radiol 1969; 4: 329-32.

2. Parodi JC, Palmaz JC, Barone HD. Transfemoral intralumina graft implantation for abdominal aortic aneurysms. Ann Vasc Surg 1991; 5: 491-9.

3. Dake MD, Miller DC, Semba CP, Mitchell RS, Walker PJ, Liddell RP. Transluminal placement of endovascular stentgrafts for the treatment of descending thoracic aortic aneurysms. N Engl J Med 1994; 331: 1729-34.

4. Palma JH, Almeida D, Carvalho AC, Geisthovel N, Gome WJ, Souza JAM et al. Utilização de endoprótese expansível ("stent") introduzida através da artéria femoral para tratamento ("stent") introduzida através da arteria femoral para tratamento 1997; 12: 372-6.

5. Stolf NAG, Pêgo-Fernandes PM, Souza LR, Moitinho RR, Costa R, Arteaga E et al. Uso da protese endovascular autoexpansível para tratamento das doenças da aorta torácica descendente. Rev Bras Cir Cardiovasc 1998; 13: 124-30.

6. Fonseca JHP. Tratamento das dissecções agudas da aort descendente, utilizando stents aórticos introduzidos pela artéria femoral. [Tese. Livre-Docência]. São Paulo: Escola Paulista de Medicina-Universidade Federal de São Paulo, 1999. 86p.
7. Fann JI, Miller DC. Endovascular treatment of descending thoracic aortic aneurysms and dissections. Surg Clin North Am 1999; 79: 551-74.

8. Borst HG, Walterbusch G, Schaps D. Extensive aortic replacement using "elephant trunk" prosthesis. Thorac Cardiovasc Surg 1983; 31: 37-40.

9. Buffolo E, Palma H. Surgical treatment of type B dissecting aneurysms: what is new? Arch Chir Thorac Cardiovasc 1997; 19: $171-2$.

10. Paula IAM, Palma JH, Branco JNR, Soldenberg S, Marcelino $\mathrm{M}$, Geisthovel $\mathrm{N}$ et al. Utilização de endoprótese auto expansível ("stent") posicionada na aorta torácica do cão. Rev Bras Cir Cardiovasc 1997; 12: 274-7.

11. Palma JH, Geisthõvel N, Brasil LA, Ferrari Jr. A, Carvalho AC, Gomes W et al. Tratamento de aneurismas da parte torácica da aorta pela introdução de "stents" sob visão endoscópica. Rev Bras Cir Cardiovasc 1998; 13: 8-12.

12. Czermark BV, Waldenberger P, Fraedrich G, Dessl AH, Roberts $\mathrm{KE}$, Bale RJ et al. Treatment of Stanford type B aortic dissection with stent-grafts: preliminary results. Radiology 2000; 217: 544-50.

3. Yoshida H, Yasuda K, Tanabe T. New approach to aortic dissection: development of an insertable aortic prosthesis. Ann Thorac Surg 1994; 58: 806-10.

14. Walker PJ, Dake MD, Mitchell RS, Miller DC. The use of endovascular techniques for the treatment of complications of aortic dissection. J Vasc Surg 1993; 18: 1042-51.

15. Kato N, Hirano T, Takeda K, Nakagawa T, Mizumoto T, Yuasa $\mathrm{H}$ et al. Treatment of aortic dissections with a percutaneous intravascular endoprosthesis: comparison of covered and bare stents. J Vasc Interv Radiol 1994; 5: 805-12.

16. Tiesenhausen K, Amann W, Koch G, Hausegger KA, Oberwalder P, Rigler B. Endovascular stent-graft repair of acute thoracic aortic dissection: early clinical experiences. Thorac Cardiovasc Surg 2001; 49: 16-20.

17. Marin ML, Lyon RT, Hollier LH, Kaplan DB. Experience with endovascular grafts in the treatment of infrarenal aortic aneurysms associated with proximal aortic dissection. Am J Surg 1999; 177: 102-6.

18. Dake MD, Kato N, Mitchell S, Semba CP, Razavi MK, Shimono T et al. Endovascular stent-graft placement for the treatment of acute aortic dissection. N Engl J Med 1999; 340 : $1546-52$.

19. Won JY, Lee DY, Shim WH, Chang BC, Park SI, Yoon CS et al Elective endovascular treatment of descending thoracic aortic aneurysms and chronic dissections with stent-grafts. J Vasc Interv Radiol 2001; 12: 575- 82. 